\title{
STRATEGI PEMASARAN HOTEL GRAND ASRILIA DI MASA PANDEMI COVID-19
}

Yuliana Pinaringsih Kristiutami ${ }^{1}$, Sandy Nugraha Raharjo ${ }^{2}$

${ }^{1}$ Akademi Pariwisata (AKPAR) BSI, Bandung, Indonesia, yuliana.pinaringsih@gmail.com:

${ }^{2}$ Akademi Pariwisata (AKPAR) BSI, Bandung, Indonesia, sandy.nugraha.raharjo@gmail.com:

\begin{abstract}
ABSTRAK
Histori Artikel

Submitted:

4 Desember 2020

Reviewed:

10 Desember 2020

Accepted:

14 Desember 2020

Published:

15 Mei 2021

Industri perhotelan merupakan salah satu industri yang memiliki kontribusi besar dalam perekonomian Indonesia. Kota Bandung merupakan salah satu daerah di Jawa Barat yang memiliki cukup banyak perusahaan perhotelan. Salah satu perusahaan perhotelan yang ada di Bandung yaitu Hotel Grand Asrilia. Namun, belakangan ini ditemukan jenis virus baru yang berasal dari Wuhan, China yang menyebabkan pandemi COVID-19 dan membawa dampak yang sangat besar bagi perekonomian Indonesia bahkan sampai seluruh dunia. Tujuan dari penelitian ini adalah untuk mengetahui strategi yang tepat bagi Hotel Grand Asrilia dalam memasarkan produknya di masa pandemi COVID-19. Metode yang digunakan dalam penelitian ini adalah metode deskriptif kualitatif dengan teknik pengambilan data observasi, wawancara, studi pustaka juga menafsirkan dan menguraikan data yang ada bersamaan dengan situasi yang sedang terjadi. Hasil dari penelitian ini, membuktikan bahwa penerapan pemasaran melalui pemasaran digital memiliki dampak positif bagi Hotel Grand Asrilia dimana penggunaan digital marketing di anggap perlu dilakukan terutama di tengah pandemi COVID-19 ini, sehingga kegiatan bisnis bisa terus berjalan dan menghasilkan nilai ekonomi.
\end{abstract}

Kata Kunci : Covid-19, Pemasaran, Hotel dan Pemasaran Digital

\section{GRAND ASRILIA HOTEL MARKETING STRATEGY ON COVID-19 PANDEMIC ERA}

\begin{abstract}
The hospitality industry is one of the most significant contributions in the Indonesian economy. Bandung City is one of the areas in West Java that has quite a lot of hospitality companies. One of the hospitality companies in Bandung is Hotel Grand Asrilia. However, lately it has been found a new type of virus that originated in Wuhan, China which caused the COVID-19 pandemic and brought enormous impact to the Indonesian economy even to the rest of the world. The purpose of this research is to find out the right strategy for Hotel Grand Asrilia in marketing its products during the COVID-19 pandemic. The method used in this study is a qualitative descriptive method with the technique of observation data retrieval, interviews, library studies also interprets and outlines the existing data in conjunction with the current situation. The result of this study proved that the application of marketing through digital marketing has a positive impact for Hotel Grand Asrilia where the use of digital marketing in the think is necessary especially in the middle of the COVID-19 pandemic, so that business activities can continue to run and generate economic value.
\end{abstract}

Keywords: COVID-19, Marketing, Hotel and Digital Marketing

\section{PENDAHULUAN}

Wabah COVID-19 kini menjadi pandemic global setelah di umumkan oleh Badan kesehatan Dunia atau WHO (World Health
Organization). COVID-19 adalah sebuah penyakit baru menular yang di sebabkan oleh sindrom pernapasan akut coronavirus 2 (severe acute respiratory syndrome 
coronavirus 2 atau SARS-CoV-2), COVID19 merupakan penyakit coronavirus jenis baru yang di temukan di Wuhan, Hubei, China pada tahun 2019 (Amri, 2020). COVID-19 menyebar luas hingga mengakibatkan terjadinya pandemi global yang berlangsung hingga saat ini. Pandemi global COVID-19 saat ini mau tidak mau memberikan dampak terhadap berbagai sektor di dunia.

Indonesia adalah salah satu negara yang terdampak oleh virus COVID-19. Hingga saat ini Perhimpunan Hotel dan Restaurant Indonesia (PHRI) mencatat hampir 40.000 pembatalan kamar hotel dengan total nilai kerugian sebesar $\mathrm{Rp} 1$ triliun rupiah ("Mengukur Dampak Wabah Virus Corona ke Bisnis Hotel," 2020).

Himbauan dari Pemerintah mengenai social distancing yang dicanangkan tanggal 31 Maret 2020 juga memprediksi dapat memberikan dampak serius terhadap penjualan hotel (Masrul et al., 2020). Tidak sedikit hotel di Indonesia yang gulung tikar karena dampak dari COVID-19 ini. Maka dari itu, diperlukan perhatian lebih dari pemerintah kepada sektor perhotelan sebagai salah satu penggerak utama perekonomian bangsa. Meskipun dampak dari COVID-19 ini sangat dirasakan berbagai sektor industri namun tidak berarti pelaku bisnis perhotelan harus berhenti dalam menjalankan usahanya. Akan tetapi hotel masih bisa menjalankan usahanya melalui pemasaran online, Karena hal tersebut tidak melanggar peraturan pemerintah terkait social distancing.

Hotel Grand Asrilia adalah salah satu hotel yang terkena dampak pandemic COVID-19 ini. Akan tetapi, hotel ini masih tetap beroperasi dengan berbagai strategi yang dilakukan untuk menjual produknya. Maka dari itu, dengan melihat uraian di atas, penulis tertarik untuk melakukan penelitian mengenai Strategi Pemasaran Hotel Grand Asrilia Di Masa Pandemi COVID-19. Hal ini dilakukan untuk dapat mengetahui secara pasti, dampak yang dialami Hotel Grand Asrilia dengan adanya COVID-19, bagaimana strategi pemasaran yang dipilih oleh manajemen hotel, serta bagaimana penerapan strategi pemasaran tersebut.

\section{LITERATUR REVIEW}

\section{Pengertian Hotel}

Hotel adalah suatu perusahaan atau badan usaha akomodasi yang menyediakan pelayanan jasa penginapan, penyedia makanan, minuman, dan fasilitas kamar untuk tidur kepada orang-orang yang melakukan perjalanan dan mampu membayar dengan jumlah yang wajar sesuai dengan pelayanan yang diterima tanpa adanya perjanjian khusus (Sujana, 2015).

\section{Pengertian Pemasaran}

Menurut Hutama dan Subagio dalam (Atmoko, 2018) pemasaran merupakan serangkaian kegiatan mulai dari proses dalam pembuatan, mengkomunikasikan mengenalkan dan menawarkan transaksi yang mempunyai nilai bagi konsumen, klien, partner, dan masyarakat pada umumnya.

Dengan kata lain, pemasaran dapat diartikan sebagai sebuah rangkaian proses yang menyeluruh, yang ditujukan untuk dapat menjembatani informasi suatu produk demi pemenuhan kebutuhan pelanggan.

Pemahaman akan bagaimana memasarkan suatu produk juga perlu dipahami lebih lanjut, agar produk yang dipasarkan dapat diterima dengan baik, serta dapat memenuhi kebutuhan serta keinginan konsumen. (Kristiutami, Brahmanto, \& Pirastyo, 2019)

\section{Strategi Pemasaran}

Strategi adalah keseluruhan konsep bagaimana sebuah perusahaan mengatur dirinya sendiri dan semua kegiatan dengan tujuan agar bisnis yang dijalankan berhasil, melakukan persaingan, dan melakukan imbal hasil kepada pemegang saham (Atmoko, 2018).

Kotler dan Amstrong mendefinisikan strategi pemasaran yaitu logika pemasaran yang digunakan perusahaan dengan harapan unit 
bisnis dapat mencapai tujuan perusahaan (Wijaya \& Santoso, 2018).

Menurut (Indrasari, 2019) terdapat beberapa faktor yang mempengaruhi strategi pemasaran yaitu: 1) segmentasi pasar, 2) pemasaran dan prospek, 3) kebutuhan, keinginan dan permintaan pasar, 4) produk atau tawaran, 5) nilai atau kepuasan, 6) hubungan dan jaringan kerja, 7) persaingan, dan 8) bauran pemasaran.

\section{Pemasaran Digital}

Digital marketing atau pemasaran digital dapat didefinisikan sebagai upaya dalam memasarkan produk atau jasa dengan menggunakan perangkat elektronik/internet dengan berbagai taktik marketing dan media digital.

Internet adalah alat yang cukup berpengaruh untuk bisnis. Internet menawarkan peluang untuk melakukan penjualan produk kebutuhan hidup sehari-hari secara langsung kepada pelanggan yang berada pada pasar konsumsi (consumer market) atau konsumen pada pasar industri seperti yang dikatakan (Pradana, 2015). Roger dalam (Purwana, Rahmi, \& Aditya, 2017) mengungkapkan ciri-ciri internet adalah sebagai berikut:

Interactivity, kemampuan perangkat teknologi memfasilitasi komunikasi antar individu seperti bertatap muka langsung. Komunikasi terjalin sangat interaktif sehingga para partisipan bisa berkomunikasi dengan lebih akurat, efektif, dan memuaskan.

Demassification, pesan dapat dipertukarkan kepada partisipan yang terlibat dalam jumlah besar.

Asynchronous, teknologi komunikasi mempunyai kemampuan untuk mengirimkan dan menerima pesan pada waktu yang dikehendaki setiap peserta.

Ada beragam akses yang dapat digunakan dalam pemasaran digital marketing, contohnya seperti media sosial. Zhu dan Chen membagi media sosial ke dalam dua kelompok sesuai dengan sifat dasar koneksi dan interaksi (Purwana et al., 2017):
Profile-based, yaitu media sosial berdasarkan profil yang fokus kepada anggota individu. Media sosial kelompok ini mendorong koneksi yang terjadi karena individu tertarik kepada pengguna media sosial tersebut contoh Facebook, Twitter, WhatsApp.

Content-based, yaitu media sosial yang fokus kepada konten, diskusi, dan komentar terhadap konten yang ditampilkan. Tujuan utamaya adalah menghubungkan individu dengan suatu konten yang disediakan oleh profil tertentu karena individu tersebut menyukainya contoh Youtube, Instagram, Pinterest.

Menurut Buyer, Juju \& Ferry, dan Bajpai, Pandey, \& Shriwas dalam (Wardhana, 2015) bahwa media sosial adalah bentuk hubungan masyarakat (humas) yang paling transparan, menarik dan interaktif pada saat ini. Media sosial cenderung lebih cepat dalam menarik perhatian dibanding interaksi langsung di dunia nyata. Momen ini kemudian dijadikan sebagai suatu jalan untuk membangun kepercayaan konsumen dengan dukungan media sosial. Sifat media sosial yang terbuka kemudian dimanfaatkan oleh pelaku usaha untuk memasarkan produknya.

\section{Situasi dan Dampak Pandemi COVID-19}

Pandemi atau pandemik merupakan tingkat atau volume penyebaran penyakit yang tergolong paling tinggi. Suatu penyakit dikatakan pandemik apabila sudah menyebar secara cepat ke seluruh dunia dengan tingkat infeksi yang tinggi (Soetjipto, 2020). Walaupun virus Corona telah dinyatakan sebagai pandemi, WHO menegaskan bahwa pandemi ini masih bisa dikendalikan. Pada saat ini pandemi yang terjadi adalah pandemi HIV/AIDS dan Corona Virus disease (COVID-19).

Angka penyebaran Corona Virus (COVID19) berdasarkan data dari Worlometers hingga selasa 19 Mei 2020 telah berjumlah 4.885.035 (4,88 juta) kasus. Dari jumlah tersebut, telah terjadi 319.779 kasus kematian. Sementara itu 1.9 juta kasus dinyatakan sembuh (Mukaromah, 2020). 
Untuk memutus rantai penyebaran COVID19, WHO maupun pemerintah menyarankan untuk melakukan pencegahan, yaitu dengan pembatasan pertemuan atau interaksi sosial (Social Distancing), melakukan seluruh kegiatan di rumah (stay at home), anjuran menjaga kebersihan lingkungan dan pribadi dengan sesering mungkin mencuci tangan dengan sabun atau hand sanitizer serta menyemprotkan disinfektan di tempat tempat berisiko tinggi penularan sampai memberlakukan PSBB (Pembatasan Sosial Berskala Besar).

Melakukan social distancing diyakini oleh sebagian orang sebagai cara yang ampuh dalam mengurangi penyebaran wabah penyakit menular. Meskipun belum ada pengukuran terhadap COVID-19, social distancing kini menjadi strategi yang digunakan untuk memperlambat laju penyebaran virus ini (Masrul et al., 2020).

Dari sisi ekonomi akibat dari kebijakan bekerja dirumah (work from home) belajar di rumah (studying from home) serta Pembatasan Sosial Berskala Besar (PSBB), para wirausahawan mengalami kerugian akibatnya banyak tempat usaha tutup karena sepi pembeli ditambah kebijakan daerah yang memberlakukan social distancing maupun jam malam membuat suasana semakin mencekam. Akibatnya banyak karyawan yang terpaksa diputuskan hubungan kerja. Dari sudut Sosial dan Budaya juga mengalami gangguan dengan pemberlakukan stay at home \& social distancing termasuk anjuran tidak mudik dan pemberlakuan PSBB membuat interaksi sosial sangat terbatas.

Dengan adanya pembatasan gerak dan interaksi, tentunya akan berimbas pada industri pariwisata yang fokus industrinya terdapat pada pelayanan dan interaksi. Sehinga, industri pariwisata menjadi industri yang paling terdampak dari pandemi COVID19 yang menyebabkan banyak dari pengusaha di bidang pariwisata dan jasa akomodasi pariwisata gulung tikar atupun tutup. Ketua umum Persatuan Hotel Republik Indonesia (PHRI) Haryadi Sukamdani di dalam kompas.com, menyatakan sampai dengan senin 6 April 2020 tercatat sudah ada 1.226 hotel tutup (Rully, 2020).

\section{METODE}

Dalam menyelesaikan penelitian ini, penulis menggunakan metode kualitatif dengan pendekatan deskriptif. Tujuan menggunakan metode kualitatif adalah agar penulis dapat menggambarkan realita empiris di balik fenomena yang terjadi terkait dengan terjadinya penurunan ekonomi akibat pandemi COVID-19 dimana Hotel Grand Asrilia harus menyusun strategi pemasaran agar hotel tetap beroperasi di tengah pandemi secara mendalam, rinci dan tuntas.

Teknik pengumpulan data dilakukan secara gabungan, analisis data bersifat deduktif, dan hasil penulisan kualitatif lebih menekankan makna dari pada generalisasi. Adapun jenis penulisan yang digunakan adalah penulisan deskriptif. Deskripsi ialah menggambarkan secara jelas mengenai fenomena lapangan.

Pada penelitian ini penulis mencari fakta tentang bagaimana strategi yang di terapkan Hotel Grand Asrilia agar hotel bisa tetap beroperasi di tengah pandemi COVID-19 dengan intepretasi yang tepat, serta akan mempelajari masalah yang terjadi di lapangan, termasuk didalamnya adalah strategi pemasaran, dan dampak-dampak pandemic yang dirasakan oleh Hotel Grand Asrilia.

\section{Teknik Pengambilan Data}

\section{Observasi}

Observasi dilakukan terhadap berbagai upaya yang di lakukan Hotel Grand Asrilia untuk bisa tetap beroperasi di tengah pandemi COVID-19, dimana pembatalan pemesanan kamar dan event sangat berpengaruh pada keberlangsungan hotel, dan keterbatasan dalam penjualan produk-produk yang di tawarkan hotel.

\section{Wawancara}

Teknik wawancara yang digunaka dalam penulisan ini adalah wawancara mendalam. Wawancara dalam penulisan ini dilakukan 
untuk memperoleh data dan informasi mengenai dampak-dapmak yang dirasakan saat terjadinya pandemi COVID-19 dan strategi yang di terapkan Hotel Grand Asrilia Bandung untuk memasarkan produknya di masa pandemi COVID-19.

Dokumentasi

Dalam penulisan ini, penulis mendapatkan beberapa dokumen berupa daily sales report dan occupancy report, Banque Event Organizer, dan expected arrival. Dokumen tersebut berupa dokumen tentang tingkat hunian dan pendapatan hotel perhari, perbulan dan juga pertahun.

\section{Lokasi Penelitian}

Penelitian ini dilaksanakan di Hotel Grand Asrilia yang terletak di JL.Pelajar Pejuang 45 no.123 Bandung.

\section{HASIL DAN PEMBAHASAN}

\section{Dampak COVID-19 yang Dirasakan Hotel Grand Asrilia}

Indonesia mengonfirmasi kasus pertama infeksi virus corona penyebab COVID-19 pada awal Maret 2020. Sejak itu, berbagai upaya penanggulangan dilakukan pemerintah untuk meredam dampak dari pandemi COVID-19 di berbagai sektor. Hampir seluruh sektor terdampak, tak hanya kesehatan. Sektor ekonomi juga mengalami dampak serius akibat pandemi virus corona. Pembatasan aktivitas masyarakat berpengaruh pada aktivitas bisnis yang kemudian berimbas

pada perekonomian.(Rizal, 2020)

Dampak dari pandemi COVID-19 membuat industri hotel sangat terpuruk dan sebagian hotel terpaksa harus menutup kegiatan operasional dan merumahkan sejumlah karyawannya. Selain itu ada beberapa hotel yang dialihfungsikan untuk tenaga medis. Sementara itu, untuk hotel yang memang masih buka, umumnya sebagai upaya agar masih mendapatkan pemasukan dan menerapkan waktu kerja bergiliran untuk mencegah penyebaran virus COVID-19.

Hotel merupakan sebuah perusahaan dalam bidang pelayanan jasa akomodasi. Banyak sekali hotel-hotel di Bandung yang menawarkan berbagai fasilitas dan pelayanan dimana persaingan pasar sangat ketat. Hotel Grand Asrilia merupakan salah satu hotel bintang 4 di Bandung, dimana hotel ini sangat diminati oleh para pebisnis dan juga instansi pemerintahan karena selain dari fasilitas kamar yang banyak Hotel Grand Asrilia juga memiliki kapasitas ballroom dan meeting room yang bermacam-macam.

Dari data yang di dapatkan oleh penulis, tingkat hunian hotel ini berkisar di 30-60\% setiap bulannya. Sedangkan untuk event Hotel Grand Asrilia bisa mengadakan event dari 20-50 event setiap bulannya. Namun saat pandemi COVID-19 terjadi, Hotel Grand Asrilia mengalami penurunan tingkat hunian dan even yang sangat drastis. Berikut adalah grafik dari occupancy dan event dalam 10 bulan terakhir:

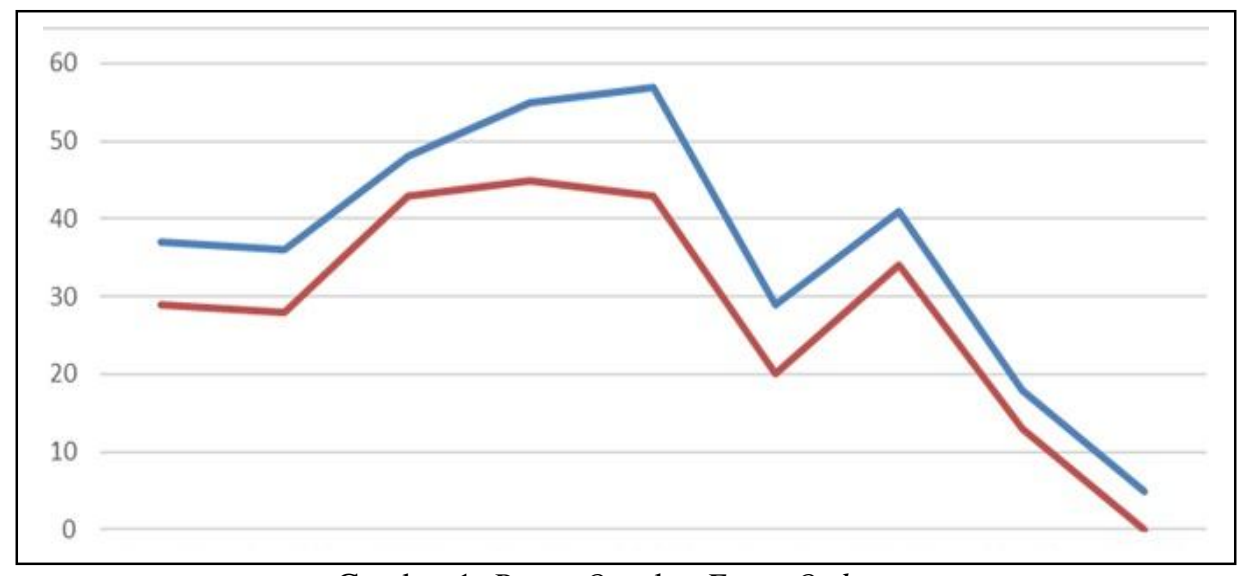

Gambar 1. Room Occ dan Event Order 
Grafik di atas menunjukan bahwa pada bulan Maret sampai April terjadi penurunan yang cukup signifikan, bahkan tidak ada sama sakali even di bulan April. Penurunan tingkat occupancy ini sangat dirasakan hotel mengingat kebutuhan operasional harus tetap berjalan. Pandemi COVID-19 ini menyebabkan kepanikan dimana tingkat kepercayaan pelanggan menurun. Selain itu, upaya yang dilakukan pemerintah dalam mengeluarkan imbauan kepada masyarakat untuk melakukan pembatasan sosial (social distancing), WFH (Work From Home) mengakibatkan Hotel Grand Asrilia tidak bisa beraktifitas seperti bisasanya.

Dampak dari pandemi COVID-19 ini membuat hotel harus terus mencari upaya agar Hotel Grand Asrilia bisa tetap beroperasi. Berbagai macam upaya telah dilakukan, mulai dari penekanan budget operasional, pengurangan karyawan, sampai merubah strategi dalam pemasaran.

Berdasarkan hasil wawancara terhadap General Manager dan staf Human Resource Department didapatkan data bahwa COVID19 membawa dampak yang nyata, terlebih posisi Hotel Grand Asrilia yang berada di pusat kota dan dekat objek wisata, sehingga penutupan area, pemberlekuan kebijakan work from home (WFH) dan pembatasan interaksi sosial turut membawa dampak terhadap turunnya pencapaian target pendapatan yang ditetepakan manajemen hotel. Penurunan pendapatan ini berimbas pula pada terhadap karyawan, dimana untuk menekan biaya, maka sebagian karyawan dirumahkan hingga waktu yang tidak ditentukan, ataupun harus diberhentikan. Walaupun dengan adanya perampingan, namun pihak hotel tetap berusaha memberikan pelayanan terbaik.

\section{Strategi Pemasaran Hotel Grand Asrilia}

Bisnis perhotelan menjadi salah satu sector yang paling terdampak oleh pandemi virus COVID-19, namun bukan berarti eksistensi hotel harus dibiarkan meredup. Pada era pandemi seperti saat ini, tingkat kepercayaan pelanggan menurun, dan pelanggan cenderung menuntut lebih terutama pada sisi penerapan Kesehatan dan kebersihan yang baik. Hotel harus bisa bertahan salah satunya dengan memberikan pelayanan dan produk yang relevan dengan situasi kondisi pandemic COVID-19.

Pelaku usaha sector pariwisata selama masa pandemic COVID-19 khususnya pelaku usaha perhotelan harus memiliki strategi untuk mempertahankan usaha mereka. Strategi pemasaran adalah sebuah taktik yang dilakukan perusahaan untuk menawarkan produk atau jasa kepada pelanggan. Setiap perusahaan ingin agar produk atau jasa yang di tawarkannya terjual, maka dari itu perusahaan harus membuat strategi dalam memasarkan produknya agar bisa bersaing dengan perusahaan lain khususnya Hotel Grand Asrilia.

Dalam upayanya untuk tetap dapat menjalankan operasional hariannya, serta menyesuaikan diri terhadap perubahan kebutuhan pasar, manajemen Hotel Grand Asrilia melakukan penyesuaian terhadap beberapa unsur marketing mix yang dijalankan pihak manajemen. Penyesuaian yang dilakukan, terfokus pada 5 hal pokok yang sesuai dengan prinsip marketing mix, yaitu product, price, people, promotion dan process. Lebih lanjut, upaya penyesuaian yang dilakukan oleh manajemen Hotel Grand Asrilia dijabarkan sebagai berikut:

Produk

Menurut (Indrasari, 2019) produk adalah setiap tawaran yang dapat memuaskan kebutuhan dan keinginan. Hotel Grand Asrilia memiliki produk yang cukup mumpuni untuk memenuhi kebutuhan tamu hotel, mulai dari fasilitas yang lengkap dan juga jumlah kamar yang cukup banyak. Selain itu Hotel Grand Asrilia menydiakan berbagai macam menu makanan dan juga minuman yang berkualitas.

Untuk dapat meningkatkan kepercayaan calon pelanggan, saat ini hotel terus meningkatkan upaya penerapan kebersihan yang ideal. Penerapan standar kebersihan yang tinggi inipun dilakukan secara merata di 
seluruh bagian hotel dengan cara melakukan penyemprotan desinfektan ke setiap tempat yang sering terkena kontak fisik, memberikan petunjuk batas terkhusus pada tempat yang dirasa dapat menimbulkan keramaian dan di haruskan mengantri, serta penyediaan hand sinitizer di setiap tempat yang sering terkena kontak fisik, seperti area lobby, elevator serta pada pintu masuk setiap ruang pertemuan.

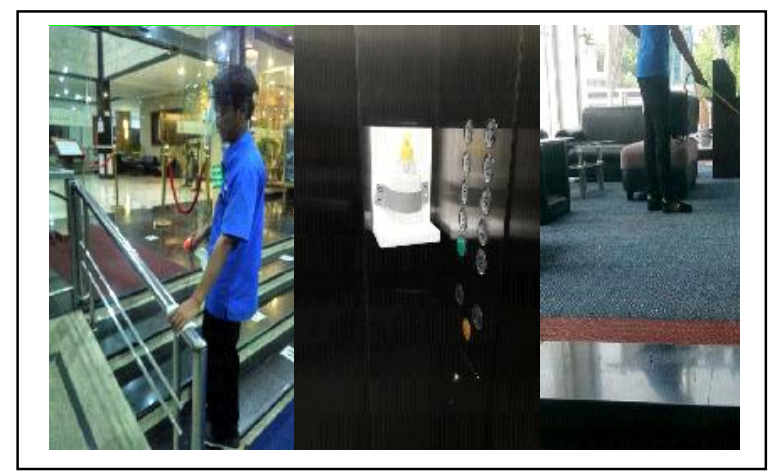

Gambar 2. Penyemprotan Desinfektan dan Penyediaan Harga hand sinitizer

Dalam penentapan harga dibutuhkan analisis matang untuk produk yang akan dipasarkan sehingga dapat dijadikan sebagai keunggulan produk yang dihasilkan oleh perusahaan. Hotel Grand Asrilia sudah menyesuaikan harga dengan standar yang ada.

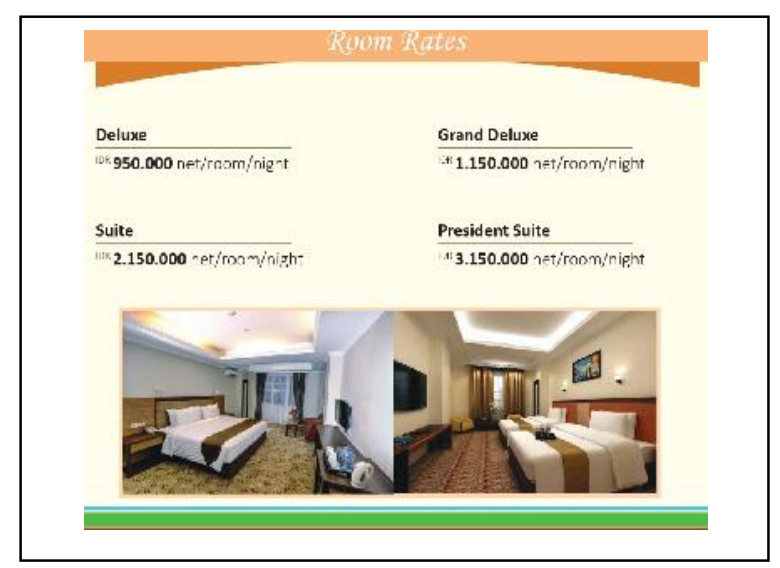

Gambar 3. Harga kamar sebelum masa Pandemi

Hotel Grand Asrilia menggunakan metode Fixed Fee Pricing yaitu menurunkan harga kamar disesuaikan dengan kondisi daya beli pasar, dimana tujuan utamanya adalah agar hotel tetap bertahan di masa pandemi COVID-19. Harga yang di tawarkan saat ini mulai dari harga Rp. 300.000,- (pada gambar
3) dari sebelumnya harga normal yang ditawarkan mulai dari Rp. 950.000,-.

\section{Orang (people)}

Karyawan adalah salah satu unsur marketing mix yang sangat penting. Hotel Grand Asrilia memiliki karyawan-karyawan yang berkompeten. Setiap bulannya hotel mengadakan training untuk para staff untuk memberikan pelayanan yang maksimal.

Untuk dapat memberikan jaminan keamanan dan Kesehatan baik bagi para pelanggan dan juga sebagai salah satu upaya manajemen untuk dapat memberikan jaminan perlindungan bagi karyawan, Hotel Grand Asrilia mengadakan tes kesehatan secara berkala bagi setiap karyawannya. Tes Kesehatan berkala dilakukan setiap 1 bulan sekali, dan wajib diikuti oleh seluruh karyawan yang masih bertugas aktif. Disamping upaya tersebut diatas, manajemen hotel juga menekankan pentingnya penerapan protokol Kesehatan ketat, dengan mewajibkan penggunaan alat pelindung diri (APD) berupa masker dan face shield untuk setiap karyawan, terutama bagi karyawan yang langsung berhadapan dengan tamu.

\section{Promosi}

Promosi merupakan proses mengkomunikasikan variabel bauran pemasaran yang dilakukan oleh perusahaan dalam memasarkan produk atau jasanya. Sejak berdiri pada tahun 2016, Hotel Grand Asrilia sudah melakukan berbagai kegiatan promosi mulai dari direct marketing, sales promotion, public relation, personal selling, interactive marketing, sampai digital marketing. Selain itu hotel juga melakukan beberapa promosi yang di tampilkan di koran sampai televisi.

Pada masa pandemi COVID-19 promosi yang dilakukan hanya dengan menggunakan digital marketing yaitu melalui sosial media atau web site.

Proses

Proses disini mencakup bagaimana cara perusahaan melayani tiap konsumennya. Proses merupakan salah satu unsur marketing 
mix yang cukup penting. Hotel Grand Asrilia selalu memberikan pelayanan terbaiknya bagi tamu atau pelanggan hotel, mulai dari pememesanan kamar atau tempat meeting yang mudah, pembayaran, proses check in sampai proses check out.

Seiring dengan peratuan pemerintah tentang menjalankan protokol kesahatan, seluruh bidang usaha ataupun instansi di Indonesia menambahkan proses dalam pelayanannya. Proses-proses yang diterapkan oleh Hotel Grand Asrilia adalah sebagai berikut: (1) Memberikan petunjuk jarak di tempat yang di haruskan mengantri; (2) Mewajibkan pengecekan suhu tubuh bagi siapapun yang hendak memasuki area hotel; (3) Mewajibkan pelanggan menggunakan masker atau face shield selama beraktivitas di area hotel.

\section{Langkah-langkah Penerapan Strategi Pemasaran}

Adanya kebijakan pembatasan aktivitas sosial di ruang publik atau Pembatasan Sosial Berskala Besar (PSBB) yang diterapkan di Bandung saat terjadi pandemi COVID-19, membawa dampak nyata bagi divisi pemasaran Hotel Grand Asrilia. Akibat penerapan kebijakan tersebut Departemen Marketing tidak dapat menjalankan tugas pemasaran secara maksimal, karena keterbatasan dalam melakukan aktifitas Sales Call yang pada umumnya menjadi salah satu cara paling efektif dalam menjaring calon pelanggan. Maka dari itu langkah-langkah dalam penerapan strategi pemasaran pun ikut berubah seiring dengan berubahnya strategi pemasaran yang dilakukan hotel.

Perubahan manajemen dalam rangka adaptasi kebijakan pemerintah tersebut adalah dengan melakukan penyesuaian segmentasi pasar yang dimiliki hotel, Segmentasi pasar yang semula menyasar pasar dalam segmen yang luas, yang mencakup pada kegiatan function $_{\text {s event, food and beverage serta }}$ penyewaan kamar. saat ini hanya difokuskan untuk menjaring pelanggan yang diharuskan untuk bepergian, dan membutuhkan tempat menginap yang berkualitas. Fokus penjaringan pelanggan juga difokuskan pada penetapan market segment hanya untuk tamu-tamu lokal.

Dalam penetapan pasar Hotel Grand Asrilia menargetkan produknya untuk pelanggan yang mencari penginapan dengan tingkat kebersihan dan kesehatan yang baik.

Kebijakan pembatasan aktivitas dan interaksi sosial juga membawa dampak nyata dalam cara Hotel Grand Asrilia melakukan pemasaran. Akibat tidak dapat melakukan kegiatan sales call sebagaimana mestinya, pihak manajemen hanya dapat melakukan promosi dan pemasaran yang terbatas melalui media digital marketing saja.

\section{Pemanfaatan Digital Marketing}

Terjadinya pandemi COVID-19 saat ini merubah segala hal termasuk budaya masyarakat. Masyarakat saat ini lebih memilih berinteraksi melalui media sosial karena beberapa imbauan dari pemerintah yang melarang berinteraksi secara langsung. Selain itu juga interaksi melalui media sosial di anggap lebih aman dan minim resiko. Hotel Grand Asrilia memanfaatkan tren tersebut dengan melakukan promosi menggunakan digital marketing, salah satunya adalah melalui sosial media. Selain karena terhambatnya aktifitas marketing dalam melakukan pemasaran, saat ini orangorang lebih memperhatikan smartphone nya. Hal ini secara tidak langsung dapat menunjang strategi pemasaran yang dilakukan oleh hotel.

Hal in juga diperkuat dengan pernyataan staf sales marketing yang menyebutkan bahwa disaat ini, aktivitas promosi yang dapat dioptimalkan hanya berupa promosi melalui media sosial.

Upaya penerapan promosi berbasi sosial media juga diperkuat dengan melakukan kolaborasi antara departemen Front Office dan Marketing. Dimana departemen Front Office menjadi pelaksana dan ujung tombak pemasaran sebagai departemen yang secara 24 jam memberikan pelayanan kepada tamu. Pemasaran melalui sosial media dilakukan dengan mengoptimalkan pengelolaan akun 
Instagram @grandasrilia.hotelbdg melalui control terhadap konten maupun narasi yang ditampilkan pada akun tersebut. Disamping itu, konten yang ditampilkan pada akun media sosial tersebut juga melakukan posting ulang (repost) konten pelanggan yang merasa puas terhadap pelayanan yang diberikan pihak Hotel Grand Asrilia. Berikut promosi yang dilakukan Hotel Grand Asrilia melalui beberapa media sosial :

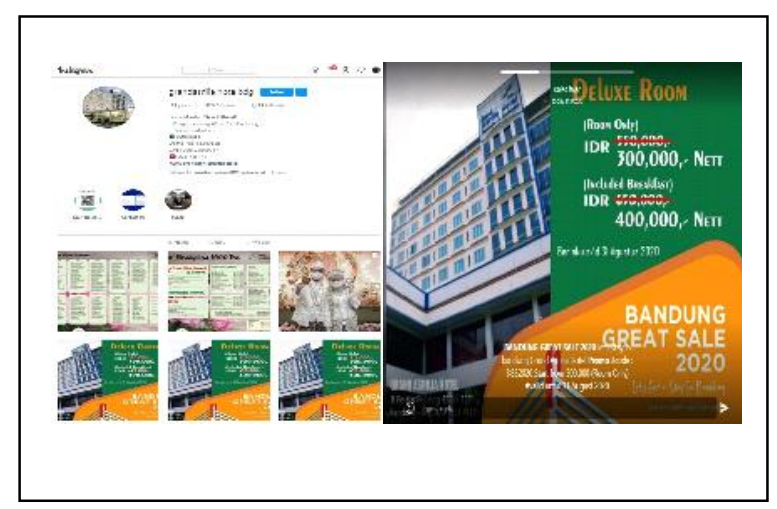

Gambar 4. Promosi Melalui Media Sosial

Penerapan promosi berbasis digital marketing yang menitik beratkan pada ulasan tentang kepuasan pelanggan maupun tamu yang menginap di Hotel Grand Asrilia mendapatkan respon positif. Sebab promosi melalui digital marketing memberikan kemudahan bagi para pelanggan terutama bagi calon pelanggan baru yang membutuhkan berbagai ulasan positif untuk meyakinkan diri bahwa pelayanan Hotel Grand Asrilia terjamin kualitas dan keamanannya. Penerapan pemasaran melalui digital marketing dapat membawa peningkatan terhadap occupancy kamar Hotel, sebagai berikut:

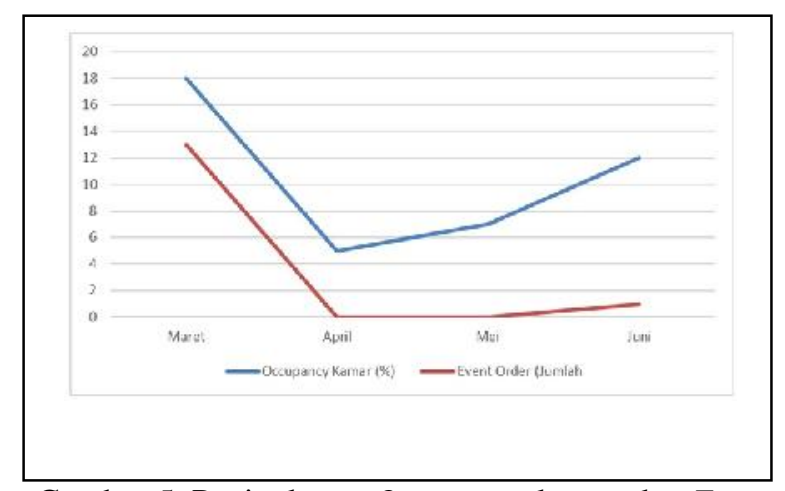

Gambar 5. Peningkatan Occupancy kamar dan Event Order
Dilihat dari grafik pada gambar 5 di atas peningkatan occupancy terjadi setelah merubah strategi pemasaran yang dilakukan Hotel Grand Asrilia. Peningkatan tersebut dapat menunjang keberlangsungan usaha Hotel selama masa pandemi COVID-19.

\section{SIMPULAN}

Berdasarkan pembahasan di atas dan dari hasil penelitian yang dilakukan oleh penulis, maka dapat di simpulkan bahwa saat ini dampak dari penyebaran corona virus atau COVID-19 ini sangat dirasakan oleh masyarakat luas, termasuk oleh para pelaku usaha di Indonesia. Upaya WHO dan pemerintah dalam pemberlakuan sosial distancing merubah budaya masyarakat saat ini dan juga berdampak negatif bagi keberlangsungan usaha setiap perusahaan khususnya Hotel Grand Asrilia. Akan Tetapi, mungkin ada beberapa upaya yang bisa dilakukan untuk menunjang keberlangsungan usaha, salah satunya adalah dengan membuat strategi pemasaran yang efektif di masa COVID-19 ini.

\section{REFERENSI}

Amri, A. (2020). Dampak Covid-19 Terhadap Umkm di Indonesia. Jurnal Brand, 2(1).

Atmoko, T. P. H. (2018). Strategi Pemasaran Untuk Meningkatkan Volume Penjualan Di Cavinton Hotel Yogyakarta. Journal of Indonesian Tourism, Hospitality and Recreation, 1(2), 83-96.

https://doi.org/https://doi.org/10.17509/ jithor.v1i2.13769

Indrasari, D. M. (2019). Pemasaran dan Kepuasan Pelanggan. Unitomo Press.

Kristiutami, Y. P., Brahmanto, E., \& Pirastyo, S. P. (2019). Implementasi Kebijakan Terhadap Persepsi Konsumen Nuart Sculpture Park Sebagai Destinasi Wisata Minat Khusus. Kepariwisataan: Jurnal 
Ilmiah, 13(3), 23-34. Retrieved from http://ejournal.stipram.ac.id/index.php/ kepariwisataan/article/view/30

Masrul, A. L. A., Simarmata, T. J., Sulaiman, D. O. K., Prianto, C., Iqbal, M., Purnomo, A., ... Faried, A. I. (2020). Pandemik COVID-19: Persoalan dan Refleksi di Indonesia.

Mengukur Dampak Wabah Virus Corona ke Bisnis Hotel. (2020). Retrieved from Kompas website: kompas.com

Mukaromah, V. F. (2020). Update Virus Corona Dunia 19 Mei. Retrieved from Kompas.com website: https://www.kompas.com/tren/read/202 0/05/19/071842565/update-viruscorona-dunia-19-mei-488-juta-orangterinfeksi-belasan-ribu

Pradana, M. (2015). Klasifikasi Bisnis ECommerce di Indonesia. MODUS, 27(2), 163.

https://doi.org/https://doi.org/10.24002/ modus.v27i2.554

Purwana, D., Rahmi, R., \& Aditya, S. (2017). Pemanfaatan Digital Marketing Bagi Usaha Mikro, Kecil, Dan Menengah (UMKM) Di Kelurahan Malaka Sari, Duren Sawit. Jurnal Pemberdayaan Masyarakat Madani (JPMM), 1(1), 117.

https://doi.org/https://doi.org/10.21009/ jpmm.001.1.01

Rizal, J. G. (2020). Pandemi Covid-19, Apa Saja Dampak pada Sektor Ketenagakerjaan Indonesia? Retrieved from Kompas.com website: https://www.kompas.com/tren/read/202 0/08/11/102500165/pandemi-covid-19apa-saja-dampak-pada-sektorketenagakerjaan-indonesia-?page=all

Rully, R. (2020). Dampak Virus Corona, 1.226 Hotel di Indonesia Tutup.
UMKM Jawa Timur.

Sujana, E. (2015). Pengaruh Karakteristik Informasi Sistem Akuntansi Manajemen (Sam), Desentralisasi, Dan Ketidakpastian Lingkungan Terhadap Kinerja Manajerial (Studi Empiris Pada Hotel Se-Kabupaten Buleleng). Journal Akuntasi, 3(1). https://doi.org/https://doi.org/10.23887/ jimat.v3i1.5121

Wardhana, A. (2015). Strategi Pemasaran Dalam Meningkatkan Tingkat Hunian Kamar Pada Hotel Bali Mandira Legian - Bali. Strategi Digital Marketing Dan Implikasinya Pada Keunggulan Bersaing UMK Di Indonesia, 327-337.

Wijaya, C. P., \& Santoso, T. P. B. (2018). Strategi Pemasaran Dalam Meningkatkan Tingkat Hunian Kamar Pada Hotel Bali Mandira Legian - Bali. Jurnal Ekonomi Dan Pariwisata, 13(1), 42-53. Retrieved from http://www.jurnal.undhirabali.ac.id/ind ex.php/pariwisata/article/view/341

\section{BIODATA PENULIS}

Yuliana Pinaringsih Kristiutami, adalah dosen tetap yayasan di kampus Akademi Pariwisata BSI Bandung dengan bidang keahlian Pariwisata dan Perhotelan khususnya mengenai manajemen pemasaran.

Sandy Nugraha Raharjo, adalah mahasiswa tingkat akhir Akademi Pariwisata BSI Bandung. Lahir di Bandung, 12 Juni 1998. Pada saat melakukan penelitian penulis kedua adalah Staff Front Office di hotel Grand Asrilia Bandung. Penulis kedua memiliki ketertarikan dalam pengembangan kualitas pelayanan di Departemen Kantor Depan.

Soetjipto, D. H. noe. (2020). Ketahanan 